\title{
ABHANDLUNGEN・ARTICLES・ARTICLES
}

\section{Tanzania's Oil and Gas Industry: Legal Regime, Management and Access Rights}

\author{
Hamudi Ismail Majamba*
}

\begin{abstract}
This article examines the extent to which the legal and management framework governing the rapidly developing oil and gas industry in Tanzania provides access rights to key stakeholders. The focus on management and access rights has been confined to rights to access the resource by the government, the private sector and the local communities. The article sets out the historical context that is necessary for a thorough understanding of the development of the industry and the legal and regulatory framework put in place by the government to address issues of management, to access rights and to control of the industry.

The analysis focuses primarily on the provisions of the recently enacted laws, the Petroleum Act, the Oil and Gas Revenue Act and the Extractive Industry Transparency and Accountability Act. These laws were passed towards the end of 2015 in a charged session of the Parliament of the United Republic of Tanzania which was the last before the gruelling National Elections that followed. Members of the opposition Parties in Parliament had cried foul, alleging that citizens had been hood-winked arguing that the process of presenting the Petroleum Bill had been unnecessarily fast-tracked. ${ }^{1}$

In the context of access rights by the government, the article's primary focus is on the legislative framework governing access to the oil and gas subsector by the government. The main focus is on Tanzania Mainland. However, in the process of analysing access rights of government, the article also brings to the fore the controversial issues relating to access rights and control of oil and gas resources between the governments of Tanzania Mainland and Zanzibar.
\end{abstract}

* Associate Professor and Dean, University of Dar-es-Salaam School of Law, Tanzania (E-mail: hmajamba@udsm.ac.tz). This article is a modified version of the paper presented to a Regional Conference for Young Researchers on "Using Natural Resources in the Interest of the People: Legal Challenges." The Conference was organized by the Rule of Law Programme for Sub-Sahara Africa (Konrad-Adenauer-Stiftung and the Tanzanian-German Centre for Eastern African Legal Studies) on $27^{\text {th }}$ October 2014 at Kebby's Hotel, Dar-es-Salaam (Tanzania).

1 See: allafrica.com/stories/201511302960.html (accessed 6 March 2016). 


\section{A. Introduction}

Oil and gas refers to the chemicals that are formed naturally as a result of the decomposition and compression of organic matter at very high temperatures over millions of years in rocks below the earth's crust. The organic matter decomposes and later forms hydrocarbons (oil and gas), which oozes through the permeable rocks and emerges on the earth, or trapped in un-permeable hard rocks. The oil and natural gas is then ready for extraction either on land or in the ocean bed. The type of natural gas that is targeted by most developers is that which is mainly used as combustion fuel (petroleum) consisting of pentane, butane, ethane and methane. Products derived from petroleum are used for, inter alia, heating and generating electricity, processing of chemicals, synthetic materials used in day to day life and fuel, such as gasoline, jet fuel, oil and diesel for transportation. ${ }^{2}$

\section{B. Overview of the Development of Tanzania's Oil and Gas Industry}

The exploration of oil and gas in Tanzania commenced during the colonial era. The earliest known discoveries were made in the southern part of the country. The history of oil and gas exploration in Tanzania can conveniently and aptly been summarized in six phases in line with the economic and political path adopted by government upon independence. ${ }^{3}$ During the first phase, 1952-1965, two British companies, Shell and British Petroleum (BP) were permitted to conducted explorations on the Islands of Pemba, Zanzibar and Mafia. Probably due to the relatively archaic technology used at that time, it would appear that these companies did not make significant findings to permit extensive operations in the areas.

The second phase in the history of the development of the oil and gas industry coincides with the nationalization of private enterprises and the subsequent establishment of State Corporations to own the major means and factors of production. The government made a concerted effort to focus on prospecting for oil in order to achieve socio-economic development. ${ }^{4}$ The government entered into a joint venture arrangement with the Italian State-owned ENI (Ente Nazionale Idrocarburi) culminating in the commencement of oil refinery operations in 1966. The initiative led to the commissioning of the Tanzania and Italian Petroleum Refinery Company Ltd under the Tanzania Petroleum Development Corporation (TPDC) where the government held 50 per cent of the shares and AGIP, who operated the refinery, held the other 50 per cent of the shares. (TPDC). Due to limited capacity, the government through TPDC entered Production Sharing Agreements (PSA) with AGIP (Azienda Generale Italiana Petroli) in order to conduct more surveys. A PSA, also referred to as a Production Sharing Contract (PSC) is a contract between a State and an International Oil

2 For more details on the basics of this subject on the first five phases see: http://oilandgasgeology.co $\mathrm{m} /$ (accessed on 20 July 2016).

3 This section is based on information primarily obtained from the TPDC website: http://www.tpdc-tz .com/ (accessed 22 February 2016).

4 See page 7 of the Energy Policy of Tanzania, 1992. 
Company (IOC) engaged in oil and gas exploration. The IOC undertakes exploration, incurring the expenses related to the risk and providing all finances related thereto, on the understanding that if nothing is unearthed the IOC will lose out. Where a discovery is made, the IOC becomes entitled to a share. ${ }^{5}$ The surveys led to the discovery of significant gas reserves in Songo Songo (Tanzania) between 1974 and 1979.

The promulgation of the Petroleum (Exploration and Production) Act in 1980 marked the commencement of the third phase in the oil and gas industry in Tanzania. Between 1980 and 1991, more discoveries were made resulting in the drilling of more wells by foreign companies from other jurisdictions, which ended the monopoly of exploration of oil and gas by British companies in the industry. The drilling was made under license from the TPDC.

Realizing it still had limited skills and capacity in the gas and oil industry, the government opted to exercise some caution in permitting full-fledged development of the industry by foreign companies. In this regard, the fourth phase era in the history of the oil and gas industry (1992-1999) saw relatively little activity in the sector in terms of exploration. The government made some effort to increase its capacity in the technical and fiscal arrangements in developing the discoveries made at the Songo Songo field. Another public utility, the Tanzania Electrical Supply Company (TANESCO), was brought into the limelight to be engaged in further expansion, transmission and operation of the gas field at Songo Songo. To ensure no cartels were developed, the government brought in more companies from other countries such as Canada and Australia to work in collaboration with the TPDC and TANESCO in the development of the industry.

The fifth phase in the evolution of the gas and oil sector in Tanzania commenced in 2000 , where the government made tremendous progress in the acquisition of geological survey data from TPDC leading to licensing of renowned powerhouses in the oil and gas industry, in the likes of Petrobas, Statoil and Dominion. Further significant discoveries have since been made and the government has re-aligned itself in putting in place a vibrant policy and legal framework in order to regulate the industry.

The sixth phase in tracing the history and development of the gas and oil subsector in Tanzania started with efforts to develop a policy on oil and gas and incorporating legislative provisions on oil and gas in activities where the government contemplated developments were likely. It is during this phase that the government commenced efforts to lay a proper foundation for a legal framework that would address upstream, downstream and midstream operations and developments in a more holistic manner by taking into account the diverse interests of various stakeholders in the oil and gas sub-sector. This phrase witnessed more discoveries of natural gas reserves, the re-negotiation of Production Sharing Agreements (PSA), promulgation of a policy and the enactment of a new Act in $2015 .^{6}$

5 See generally Allen and Overy, Guide to Extractive Industries Document - Oil and Gas, World Bank Institute, 2013.

6 See: http://www.tmgof.or.tz/tanzania-make-new-natural-gas-discovery-in-ruvu-basin/. 


\section{Review of the Legislative Framework}

Like any other legal regime in common law jurisdictions, that governing the oil and gas subsector in Tanzania is fragmented and found in numerous seemingly unrelated sectors. These include ancillary laws that may be very easily overlooked in an analysis of the sector's legal framework and the implications of their provisions to the oil and gas industry brought to the fore.

As noted above, the enactment of the Petroleum (Exploration and Production) Act in 1980 in the third phase of the historical development of the oil and gas industry in Tanzania ushered in the first legislative framework for the oil and gas sector as noted above. The overall legislative framework governing issues of management and access rights in relation to the oil and gas industry in Tanzania must be viewed from this historical context. A synopsis of this history is critical in understanding the application of the body of legislation in the United Republic of Tanzania generally and that regulating the oil and gas industry in particular.

Germany's control of Tanganyika (now Tanzania Mainland) came to end after its defeat in the First World War and the colony was subsequently handed over to the British under the mandate of the League of Nations as a Trust Territory before it became independent with a Constitution in 1961. Across the Indian Ocean, approximately $40 \mathrm{~km}$ east of independent Tanganyika, was another country called Zanzibar. It was also under the British, as a Protectorate with an Arab Sultan. Zanzibar covered an area of close to 1,000 sq. km, consisting of two Islands, Pemba and Unguja, and it attained independence in 1964 with an Independent Constitution. The governments of Tanganyika and Zanzibar decided to merge on $22^{\text {nd }}$ April 1964 to form a Union, one sovereign Republic, the United Republic of Tanzania, four days later. A lot of ink has poured on the reasons behind the merger between Tanganyika and Zanzibar, including matters surrounding its legality. We would not attempt to address the contentious issues raised in this rather controversial discussion due to the scope to which this article is confined, save for the observations that follow immediately on the impact of the merger on the sharing of oil and gas resources among the two entities. ${ }^{7}$

\section{Access of Oil and Gas in the Context of the Union - the Zanzibar Factor}

Under the Union Agreement in 1964, there was established an arrangement where some issues were to be regulated by the Union government, the United Republic of Tanzania. The-

7 For an all-embracing coverage of some of the controversies see Shijvi, Issa G. et al, Constitution and Legal System of Tanzania: A Source Book, Mkuki na Nyota Publishers, Dar-es-Salaam 2004; Shivji, Issa G., Pan-Africanism or Pragmatism? Lessons of Tanganyika and Zanzibar Union, Mkuki na Nyota Publishers, Dar-es-Salaam 2006 (and the review of this publication by Majamba, Hamundi I. in CHEMCHEMI Bulletin, Mwalimu Nyerere Professional Chair in Pan African Studies, University of Dar-es-Salaam, Tanzania. Issue No. 1, April 2009 and http://www.academia.edu/1312204 0/Review_of_Issa_Shivjis_Pan-Africanism_or_Pragmatism_Lessons_of_Tanganyika_and_Zanzibar _Union. 
se are referred to as "Union matters" under the Constitution of the United Republic of Tanzania. Under the framework of the Union matters, Zanzibar ceded its autonomy on all those matters provided for in the list of "Union matters." Among these were issues relating to oil and gas as stipulated in item 15 of the First Schedule of the Constitution, which provides:

"Mineral oil resources, including crude oil, other categories of oil or products and natural gas" are a Union matter.

We should point out here that the 1964 Agreement provided for the procedure to be followed to add, delete or amend the list of Union matters. Accordingly, Article 98 (1) (b) of the Constitution of the United Republic of Tanzania provides for the procedure to amend the Constitution generally and item 7 of the Second Schedule of the Constitution clearly states that the list of Union matters can be added, deleted or amended.

The inclusion of oil and gas in the Constitution of the United Republic of Tanzania became a major bone on contention that has threatened the existence of the unique Union between the two entities. In April 2009, the Zanzibar House of Representatives passed a resolution declaring that natural resources (oil and gas included) are not a Union matter. This resolution culminated in the amendment of the Zanzibar Constitution in 2010, resulting in the removal of oil and gas from the list of Union matters. The legality of the amendment remains controversial in view of the fact that the Constitution of the United Republic of Tanzania provides for the procedure for amending the list of Union matters. The procedure does not envisage the avenue taken by the House of Representatives. An in-depth analysis of this controversy is certainly beyond the scope of this paper. Suffice to point out, however, that although the now defunct proposed draft Constitution of the Constitution of the United Republic of Tanzania does not have oil and gas in the list of Union matters, the controversy is bound to recur when the government of the United Republic of Tanzania will be required to address the international dimensions of oil and gas matters. This is because international relations remain to be a Union matter and international legal instruments which have been ratified by the United Republic of Tanzania fall under international relations. ${ }^{8}$

Having set out the context above, it is prudent to re-echo at this juncture that this article focuses on the oil and gas industry existing only on Mainland Tanzania. It does not address the industry in the context of Zanzibar for the reasons alluded to above. In this regard, one contemplating to get an idea of the oil and gas industry must take into account that there is a separate legislative regime governing the industry in Zanzibar which certainly has a bearing on the oil and gas sub-sector. Suffice to point out that the drafters of the Petroleum Act, 2015 make a vivid attempt to address the contentious issue in order to avert a threat of a breakdown of the Union as will be discussed below. 


\section{E. Sources of Law for Oil and Gas}

The British colonial administration imposed a heavy dose of the common law legal system in Tanganyika. The independence government of Tanganyika adopted this system wholesale. In this regard, the sources of law in Tanzania, in line with the common law tradition comprises of international law, the Constitution, laws enacted by Parliament (principal law) and those enacted under the authority of Parliament (subsidiary law). The other important source of law is found in precedents - decisions of courts of record. We will not dwell on customary and Islamic laws which also form part of the general corpus of sources of law of Tanzania. These do not have a direct application in relation to the oil and gas industry. However, we will cover customary law, in passing where applicable, especially in relation to land tenure issues. Other ancillary laws seek to regulate the environment, local government activities and land tenure have an impact on the sub-sector and will also analysed to the extent of the likely impact of the application of their provisions.

\section{The Constitution of the United Republic of Tanzania}

The Constitution of the United Republic of Tanzania implicitly makes reference to oil and gas where it places a duty on citizens to protect the country's natural resources.

Article 27 of the Constitution provides:

“(1) Every person has the duty to protect the natural resources of the United Republic, the property of the state authority, all property collectively owned by the people, and also to respect another person's property.

(2) All persons shall be required by law to safeguard the property of the state authority and all property collectively owned by the people, to combat all forms of waste and squander, and to manage the national economy assiduously with the attitude of people who are masters of the destiny of their nation."

Broadly construed this provision caters for oil and gas resources as natural resources have been defined to include mineral and fossil fuels. ${ }^{9}$ In this regard, this constitutional provision provides the underlying basis for the legal framework for oil and gas in Tanzania.

\section{International Legal Instruments}

Aside from the Constitution, it should be pointed out at the outset that international legal instruments ratified by the United Republic of Tanzania form part of the law of the country. Tanzania follows the dualist approach in relation to the treaties and other international legal instruments. Accordingly, the government is required by the Constitution to submit any in-

9 http://www.businessdictionary.com/definition/oil.html (accessed on 20 July 2016). 
ternational legal instruments to the Parliament for ratification. ${ }^{10}$ Once the treaty has been ratified, it does not become part of the law until it is domesticated by principal of subsidiary legislation.

The international legal instruments that have a bearing on the gas and oil industry that one should take into account when discussing the body of laws governing the oil and gas industry in the country fall into various categories. There are those that make specific reference to oil. Others have an indirect bearing to oil as they relate to safety, solid and liquid waste, toxic substances, air pollution and conservation of fauna and flora. These place duties and obligations relating to oil spills causing destruction to the environment on companies and investors. They also reflect the principle of national sovereignty over natural resources.

International legal instruments that are closely related to the oil and gas industry in Tanzania include the United Nations Convention on the Law of the Sea 1982 (UNCLOS), ${ }^{11}$ the Convention on the International Regulation for Preventing Collision at Sea, 1972, ${ }^{12}$ the International Convention for the Safety of Life at Sea, $1974,{ }^{13}$ the International Convention for the Prevention of Pollution from Ships (MARPOL) ${ }^{14}$ and the International Convention on Oil Pollution Preparedness, Response and Co-operation of 1990 (OPRC). ${ }^{15}$

Also in this list are the International Convention on Civil Liability for Oil Pollution Damage (CLC) $1969,{ }^{16}$ the International Convention on Civil Liability for Bunker Oil Pollution Damage 2001(Bunkers Convention) $1976^{17}$ and the Convention on the Prevention of Marine Pollution by Dumping of Wastes and Other Matter of $1972 .{ }^{18}$ Others are the International Convention for the Prevention of Pollution from Ships (MARPOL), $1973^{19}$ and its related Protocols, the Nairobi International Convention on the removal of Wrecks 2007, ${ }^{20}$ the Hong Kong International Convention for the Safe and Environmentally Sound Recycling of Ships of $2009,{ }^{21}$ the Basel Convention on the Control of Transboundary Movements of Hazardous Wastes and their Disposal, $1989^{22}$ and related Protocols. Also in this

10 This is provided for by Article 63 (3) (e.) of the Constitution of the United Republic of Tanzania.

11183 UNTS 3.

12 See Lloyd's Register Rule Finder, 2005 version 9.4.

131184 UNTS 2.

1412 ILM 1319 (1873).

151891 UNTS 51.

1693 UNTS 3.

17 UKTS No. 8 (2005).

181046 UNTS 120.

1912 ILM 1319)1973).

20 Available at: https://www.gov.uk/government/uploads/system/...data/.../8243.pdf (accessed 20 June 2016).

21 Available at: http://www.basel.int/Portals/4/Basel\%20Convention/docs/ships/HongKongConventio n.pdf (accessed on 20 June 2016).

221673 UNTS 57. 
category are the International Convention on the Control of Harmful Anti-fouling Systems on Ships, 2001(AFS), ${ }^{23}$ the Montreal Protocol on Substances that Deplete the Ozone Layer, 1987 (Montreal Protocol) under the 1985 Vienna Convention for the Protection of the Ozone Layer ${ }^{24}$ and the International Convention for the Control and Management of Ships' Ballast Water and Sediments, 2004. ${ }^{25}$

Conventions whose provisions focus on protecting flora and fauna in relation to the oil and gas sub-sector are found in the Convention on Wetlands of International Importance $1971,{ }^{26}$ the World Heritage Convention, 1972, ${ }^{27}$ the Convention on International Trade in Endangered Species of Wild Fauna and Flora 1973 (CITES), ${ }^{28}$ the Convention on the Conservation of Migratory Species of Wild Animals 1979 (CMS), ${ }^{29}$ the Convention on Biological Diversity $1992^{30}$ and the Convention on the Protection of the Underwater Cultural Heritage $2001 .{ }^{31}$

\section{Principal Legislation}

The Parliament has enacted a number of laws that have a bearing on the exploration of oil and gas industry in Tanzania. These are the main laws that have been applied to regulate the oil and gas industry. The enactments by the Parliament are supplemented by subsidiary laws made by other authorities under the oversight of the Parliament.

It should also be pointed out that being a cross-cutting sub-sector, the oil and gas industry certainly requires regulation by a whole range of legislative enactments due to its likely spill over effects into other sectors. These include ancillary legislation regulating the incorporation of companies, investment, taxation, land and environment. In this category, therefore, it is necessary to keep in mind the provisions of the Investment Promotion Act, the Companies Act, Income Tax Act, the Land Act and Village Land Act and the Environmental Management Act. Legislation that has been put in place to govern urban and local government authorities that is the Local Government (District Authorities) Act and Local Government (Urban Authorities) Act also contain provisions that have a significant bearing on the oil and gas industry. This review addresses only those laws that have a direct bearing on the oil and gas industry and refer to the ancillary laws in passing where necessary.

23 Available at: https://www.gov.uk/government/uploads/system/uploads/attachment_data/file/23610 2/8284.pdf (accessed on 20 June 2016).

241155 UNTS 331.

25 Available at: https://www.classnk.or.jp/hp/pdf/activities/statutory/ballastwater/imo/bwmcirc_24.pd $\mathrm{f}$ (accessed on 20 June 2016).

26996 UNTS 245.

271037 UNTS 151.

28993 UNTS 243.

291651 UNTS 338.

301760 UNTS 79.

3141 ILM 37. 


\section{Petroleum Act, 2015}

The Petroleum $\mathrm{Act}^{32}$ repealed and replaced the Petroleum (Exploration and Production) Act of 1980. It is the principal framework legislation for oil and gas, containing 261 sections, 12 Parts and Three Schedules. The preamble to the Act, which is part of the law, provides for the reasons for its establishment. ${ }^{33}$ Accordingly, the Act was established to make provision for the regulation of petroleum activities being carried out at the upstream, downstream and midstream. The Petroleum Act establishes the Petroleum Upstream Regulatory Authority (PURA), the National Oil Company and seeks to secure accountability of petroleum entities operating in the country.

The Petroleum Act is to read with two other important pieces of legislation; the Oil and Gas Revenues Management Act and the Tanzania Extractive Industries (Transparency and Accountability) Act. ${ }^{34}$ The former is relevant in this analysis in so far as it sets out to protect access of oil and gas resources by the future generation putting in place and Oil and Gas Fund under the control of the Central Bank. ${ }^{35}$ The latter seeks to limit access of those who may want to embezzle or misappropriate revenues derived from the oil and gas subsector by establishing a Committee, independent of government, to ensure transparency and accountability in the sub-sector. ${ }^{36}$

\section{a) Access by Government}

Like all sector laws on natural resources in Tanzania which vests radical title in the government, the Petroleum Act vests title to petroleum deposits in the country in the United Republic to be managed by the government as trustee of the people of Tanzania. ${ }^{37}$ The approach of vesting natural resources in the government as trustee of the people is traced to ancient Rome in the doctrine of public trust in environmental and natural resources management parlance. The doctrine is premised on the Roman theory that important resources such as water and air should not be owned by a few individuals in society. Rather they should be vested in the Sovereign who would hold regulate their use by citizens as trustee. The overall effect of vesting the management and ownership of petroleum deposits to the government restrict direct access to the resources by citizens.

Section 4 of the Petroleum Act, also has a bearing on access of petroleum resources found on the United Republic in the context of the Union between Tanzania Mainland and

32 No. 21 of 2015.

33 Section 25 (1) of the Interpretation of Laws Act, Cap. 1 [R.E. 2002] provides that a Preamble to an Act forms part of the law.

34 Act No. 22 of 2015 and Act No. 23 of 2015, respectively.

35 The Fund, which is contemplated by section 125 of the Petroleum Act, is established by section 8 of the Oil and Gas Revenues Management Act.

36 The Committee is established by section 4 of the Act.

37 See section 4 of the Act. 
Tanzania Zanzibar. This section has been cautiously gauged by the draftsman to avoid an impasse between Zanzibar and Tanzania Mainland on the controversy surrounding the ownership, control and access to oil and gas resources between the governments of Mainland and Zanzibar. The impasse culminated into the government of Zanzibar changing its constitution and consequently placing oil and gas under its jurisdiction, in total disregard of the Constitution of the United Republic of Tanzania, which places oil and gas in the list of Union matters and provides for the procedure to amend the items in the list of Union Matters. ${ }^{38}$

The Zanzibar House of Representatives had no mandate to effect the change and in any event it did not follow the laid down procedure in its resolve to 'remove' oil and gas from the list of Union matters. It should be noted that even after Zanzibar changed its Constitution, placing oil and gas under its charge, section 2 of the Petroleum (Exploration and Production) Act of 1980 had still provided that the law shall apply to Zanzibar. ${ }^{39}$ In this regard, there was a conflict of law until the enactment of the Petroleum Act in August, 2015.

In attempt to resolve the impasse, section 4 of the Petroleum Act seeks to re-echo section 2, which distinguish activities undertaken within the jurisdiction of Mainland Tanzania and those undertaken in Zanzibar. Accordingly, where petroleum is found in overlapping jurisdictions, the two governments may enter into joint petroleum operations or activities under arrangement. So, in vesting radical title of ownership in the government of the United Republic of Tanzania, section 4 clearly states that the right to manage and access petroleum resources does not extend to Zanzibar.

It is submitted that the attempt by the draftsman to avoid the political impasse in terms of management and access of oil and gas in the context of the governments of Tanzania Mainland and Zanzibar remains futile. The conflict over right to access of oil and gas between the two governments, it is submitted, cannot be resolved by the provisions of the Petroleum Act (or any law for that matter) because the Constitution of the United Republic of Tanzania still provides that oil and gas are a Union matter. In this regard, section 2 and section 4 of the Petroleum Act are ultra-vires the Constitution of the United Republic of Tanzania. The draft Bill that was proposed by the Expert Panel clearly stated that the Act should apply to Mainland Tanzania only. The draftsman of the Bill that was sent to Parliament had also made a very weird and hopeless attempt to address the impasse relating to right of access to oil and gas by the governments of Tanzania Mainland and that of Zanzibar. Section 2 of the Bill had provided: "Unless constitutionally required otherwise, this Act shall apply to Mainland Tanzania as well as Tanzania Tanzania (sic) Zanzibar."

\section{b) Institutional Framework}

The Petroleum Act vests the overall control over access and the general administration and management of oil and gas sub-sector in five main organs. These are the Minister, the Oil

39 See: https://www.tzaffairs.org/2009/09/zanzibar-the-union-and-oil/ (accessed on 20 July 2016). 
and Gas Advisory Bureau, the National Oil Company, the Petroleum Upstream Regulatory Authority (PURA) and the Energy and Water Utilities Regulatory Authority (EWURA). An assessment of the powers and functions of the five main organs bring to the fore critical issues in relation to access rights by stakeholders in the management of the oil and gas subsector.

The powers and functions of the Minister, the overall manager of the sub-sector, are provided for in section 5 of the Act. The Minister's power to develop, implement and review policies and regulations and set standards for safety and public health and environment have a significant bearing on access rights by developers and citizens in the oil and gas sub-sector. The Minister is required to consult relevant sector Ministries in the course of undertaking his functions under the Act. ${ }^{40}$

The Commissioner for Petroleum Affairs advises the Minister on matters of policy, plans and regulations. ${ }^{41}$ Sections 43 (1) and 52 (1) of the Act gives the Minister powers to grant or revoke licenses, respectively thereby welding the power to limit access to oil and gas resources.

The Oil and Gas Advisory Bureau provided for by section 7 of the Act is the overall authorizing authority, strategically located at the President's office. The Bureau is charged with advising the Cabinet on strategic issues relating to the oil and gas sub-sector. The powers, composition, qualifications of its members and functions of the Bureau are, however, conspicuously not provided for by the Act. This omission is certainly not inadvertent as the process leading to its creation during the deliberations of the Expert Panel on the draft Bill was hotly debated and the consensus was that the functions be provided for. It would appear that the draftsman opted not to follow the advice of the Expert Panel on this. The underlying basis for placing this organ under the office of the President was to ensure one line of authority in directing issues relating to the sensitivity of the oil and gas sub-sector, and taking into account the cross-sector involvement in the management of this sub-sector. ${ }^{42}$ The lack of providing for the functions, composition and powers of the Bureau in the Act, however, does not augur well with the transparency required in the oil and gas subsector, especially in view of the Extractive Industries (Transparency and Accountability) Act, 2015 which was passed together with the Petroleum Act during the same Parliamentary session. The concept of transparency in this context has a significant bearing to the right to access oil and gas resources.

Section 8 of the Petroleum Act designates the Tanzania Petroleum Development Corporation (TPDC) as the National Oil Company charged with undertaking the country's commercial aspects in all areas of the sub-sector. ${ }^{43}$ TPDC has also been vested with the manda-

40 Section 5 (3) of the Petroleum Act.

41 Ibid. Section 6.

42 The author of this article was part of the team that was involved in the deliberations of the Bill.

43 TPDC was established in 1969 by Tanzania Petroleum Development Corporation (Establishing) Order, GN 140 of 1969. 
te of overseeing the government's interests in petroleum and natural gas agreements. TPDC's overall functions are provided for by section 9. The functions that are specifically related to access rights are those that give exclusive rights over the natural gas downstream and midstream value chain. In undertaking this exclusive function, TPDC is vested with power to own and operate natural gas infrastructure, acquire, analyse and disseminate information related to the natural gas industry and own gas pipelines from the source to the end user. ${ }^{44}$ Access rights to oil and gas are limited by sections 44 (3) and 44 (6). The former provides that a license granted to TPDC shall not be transferable to another person while the latter provides that access to operations in Tanzania outside the scope of reconnaissance permit is not allowed and in the event this is to be done, it shall be done together with TPDC.

Another important management organ that has implications for access rights in the oil and gas sub-sector is the Petroleum Upstream Regulatory Authority (PURA) established under section 11 of the Act. It's functions are provided for by section 12 but in essence these are confined to upstream activities, entailing geographical exploration for and development of petroleum, constructing wells, operating pipelines and related infrastructure. It also has exclusive rights to trade and supply gas locally and internationally and to promote local content and participation of citizens in the natural gas value chain.

PURA is also required under section 12 of the Act to advise the Minister on promotion, bidding and negotiation of production sharing agreements. It has also been vested with power to grant, review, suspend or cancel exploration and development licenses and petroleum permits. Section 13 (1) (d) and (e) of the Act requires PURA to ensure transparency, fairness and balance interests between the government and other stakeholders in the course of undertaking its functions. Despite this assurance, voices have been raised by a cross section of stakeholders alleging that the exclusive rights granted to PURA do not provide a fair playing ground for others. Apparently, the voices raised in relation to the power given to PURA under the Act to regulate petroleum activities may have a basis for concern when a critical review of the provisions of the Act is made, as evidenced in the analysis that follows.

\section{c) Access to Data and Information}

Section 84 (6) of the Petroleum Act provides for the right of citizens to access data relating to agreements, licenses and permits granted under the Act through a registry maintained by PURA. Prima facie, this seems to be a welcome development as it complies with Constitutional and international legal instruments' provisions guaranteeing citizens the right to receive and access information, especially in oil and gas activities which could have an adver-

44 See section 9 (2) of the Petroleum Act. 
se impact on the environment. ${ }^{45}$ The requirement for access of data by the public in section 84 seems to be complimented by section 91 which requires PURA, with written approval of the Minister, to make available to the public all details of activities by various players in the oil and gas industry upon payment of a prescribed fee.

Subsequent sections on access to data, however, make a bluff of the preceding sections. Section 91 (1) (a) and (b) provides that data submitted by a license holder to PURA shall be confidential and shall not be reproduced or disclosed to a third party! It qualifies this by providing for an exception - unless the disclosure is sanctioned by the license/permit holder (after written authorization from Minister) and by PURA. Section 92 of the Act seeks to protect confidentiality of data and thereby limit access to such data. It provides that data submitted to PURA by a license/permit holder shall be confidential and shall not to be disclosed to third parties except when required by government or for purposes of arbitration and statistics. ${ }^{46}$

Information provided by a license or permit holder may not be disclosed to any person save with the consent of the license or permit holder, except if such information is disclosed to a PURA official or a public servant as stipulated by section 93 (1) of the Act. ${ }^{47}$ This provision contravenes other provisions of the Act which seek to provide the right to access information of license or permit holders by the public.

EWURA, which only deals with downstream and midstream gas activities, is another entity with the right to access data in the oil and gas sub-sector. EWURA has the legal mandate to maintain all information in the National Petroleum and Gas Information System (NPGIS), a strategic tool for informing the public about the status of the oil and gas industry in the country. Section 124 (5) of the Act requires all information on NPGIS except that which protects security of the State or proprietary market data or as determined by EWURA, to be made available to the public. The Act, however, does not provide for a definition of what amounts to "security of the State," leaving it to authorities to construe the word arbitrarily. In some cases leeway for such construction has been used to the detriment of the public and the court had to intervene. ${ }^{48}$

Section 48(1) of the Petroleum Act clearly states that Petroleum Agreements shall be subjected to a transparent and competitive public tendering process. However, the section does not state that the Agreements shall be made available for public scrutiny as demanded

45 See Article 18 (a) and (b) of the Constitution of the United Republic of Tanzania, Cap. 2 [R.E. 2002] and the Convention on Access to Information, Public Participation in Decision Making and Access to Justice in Environmental Matters (Aarhus Convention), 1988, 2161 UNTS 447.

46 See section 92 (3) (a).

47 Section 94 gives PURA unlimited power to extract information relating to prospecting or development operations from any person and whoever refuses to do so commits an offence under section 95.

48 See Attorney General vs. Sisi Enterprises Ltd (Civil Appeal No. 30 of 2004) Court of Appeal of Tanzania, at Dar-es-Salaam (unreported) but available at: www.saflii.org/tz/cases/TZCA/2005/2.ht $\mathrm{ml}$ (accessed on 31 March 2016). 
by a cross section of stakeholders. It would appear that calls for providing for rights of citizens' to access such Agreements has, once again, fallen on deaf ears.

\section{d) Access to Land}

As noted above, the Minister, on the advice from PURA, has power to limit access to land where petroleum resources are located through the licencing system under the Act. Section 50 (1) and (5) of the Act empowers the Minister, on his own motion or after advice by PURA, to declare certain blocks to be reserved for public purposes or to be owned directly by the National Oil Company and after such declaration the tendering process is waived. The Minister's discretionary power under this provision may be used to arbitrarily limit access to oil and gas resources by other stakeholders, as the Minister is not required to consult any person. Further as noted above the lack of defining the term "public interest" in the Act leaves room for abuse especially where the transparency contemplated by the tendering process is waived.

A licence holder's rights to access certain lands are restricted under the Petroleum Act. Section 80 (1) of the Act limits the licensee from accessing public land, burial sites, land near government buildings, aerodromes and reserved land or protected monuments. The licensee must get written consent of the Minister to access these areas. The license holder must get written consent of a lawful occupier of any land to access land held by such occupier for settlement or agricultural purposes for development activities. ${ }^{49}$ The license holder is also restricted in accessing national parks, game reserves, forest reserves and conservation areas unless granted permission by PURA. ${ }^{50}$ The power given to PURA to grant permission in such areas does not make reference to other authorities vested with the management of protected areas and reserves under the laws establishing such areas and reserves. In fact these laws do not even make reference to PURA. In this regard, this administrative provision is likely to cause conflicting mandates among institutions charged with overseeing the conservation and management of protected areas and reserves and create tension with regard to access rights.

The limitation of access to land occupied by citizens by developers in this regard seems commendable as it seeks to protect the tenurial rights of occupiers. However, the law provides that the consent of the occupier may not be necessary if it is in the opinion of the Minister it is unreasonably being withheld.' This provision leaves a lot of discretion to the Minister and places the rights of occupiers of land in jeopardy, especially taking into account that there is also no provision for compensation for land acquired under this section.

Section 110 (1) of the Petroleum Act provides for access to land for grazing livestock or cultivation by local communities in the vicinity where operations relating to oil and gas are being undertaken. However, access to such land is limited to where the grazing or cultivati-

49 Section 80 (1) (b) of the Petroleum Act.

50 See section 80 (1) (c). 
on does not interfere with the operations authorized by the provisions of the Act. Section 110 (2), for example, provides that the lawful occupier of land in an area where operations relating to oil and gas are being conducted is prohibited from erecting any building or infrastructure without the written consent of the holder of a development license. Again, in this case, the law provides that where the developer unreasonably withholds consent, the Minister shall intervene and provide such consent. There is no provision for determining what amounts to 'unreasonable', once again leaving a lot of discretion to the Minister.

The critical issue of compensation where access rights are inhibited is addressed by section 111 (1) which provides for compensation to a lawful occupier of land where damage to property, due to operations has occurred. Accordingly, the license holder is required to pay such compensation which is fair and reasonable. Section 111 (2) provides that where the value of the land of an occupier has been enhanced by exploration or development operations, the compensation to be paid to the lawful occupier by the license holder shall take into account the enhanced value of the land. Section 111 (3) provides that where the amount of compensation to be paid is in dispute, the matter shall be resolved by PURA, in accordance with the dispute settlement provisions contained in Part XI of the Act. Section 112 gives power to the President to grant a license holder a right of occupy for unoccupied land. The President's power to access alienated land here is not subject to the requirement of public interest, which in any case, as noted above, has problems. The President only needs to be satisfied that such land is required and necessary for development.

Development and operations in the oil and gas sub-sector inevitably lead to license holders accessing land for installations, repair and construction of pipelines and other facilities. In an attempt to provide for the regulation of such activities, section 185 provides that the licensee in this case shall have to comply with the Gas Utilization Master Plan and directives issued by EWURA and other relevant authorities. Section 186 is also relevant in terms of access to land by license holders or developers in the oil and gas sub-sector. It provides for acquisition of way leaves by developers, in consultation with relevant authorities, to enable them access future gas infrastructure and petroleum operations. Way leaves, though not defined in the Act, comprise of a right of way usually granted by a legal occupier of land where gas infrastructure is likely to pass, usually in exchange of payment. This arrangement is usually temporary and does not transfer ownership of land. Section 186(2) provides that owners of property on a boarder with way leaves are not to interfere with the rights of a licensee. Pipelines and related infrastructure usually have negative and adverse impact on property where way leaves are granted. Apparently, it is in this context that section 186 (3) makes provision for compensation for way leave granted and any dispute arising out of this arrangement is to be settled 'in accordance with the Land Acquisition Act, Cap. 118' ${ }^{51}$

Licensees have the right to access and use roads, streets and other infrastructure for purposes of laying, connecting, running or maintaining gas infrastructure as approved by EU-

51 This is a misnomer as the law is not applicable in such circumstances. 
WRA. ${ }^{52}$ Section 235 makes it an offence to refuse to provide access or otherwise obstruct a license holder from undertaking an activity that is licensed. Any person found guilty of doing so is liable to a fine not exceeding 20 million Tanzania Shillings or to imprisonment for a term not exceeding five years or both.

\section{e) Accessing Courts}

Section 242 of the Act lays out the dispute settlement procedure in the event of conflicts in upstream operations between persons engaged in development or operations or explorations among themselves and other parties, except disputes involving the Government. Accordingly, PURA has been vested with immense powers in the dispute resolution process under the Act. Section 242 (2) and (3) gives power to PURA to refuse to decide (entertain) any dispute brought before it and no appeal lies before any court to challenge PURA's decision to refuse to entertain a dispute. The law does not provide that PURA must state its reasons for such refusal or even provide for conditions under which it may decide not to entertain a matter. Section 243 provides that when PURA decides to entertain a dispute, it may make a decree or order and any such decree or order becomes enforceable like any other order or decree of a court.

Disputes relating to downstream regulated activities are to be resolved by EWURA as provided for by section 247 (1) but parties may opt to go to courts with competent jurisdictions and thereby by-pass EWURA. Appeals from EWURA are to be settled by the Fair Competition Tribunal within 14 days from the date of the decision by EWURA, where parties agree to send their disputes to EWURA. ${ }^{53}$

An overall assessment of the dispute settlement provisions reveal that the powers given to PURA and EWURA under the Act limit access to courts by stakeholders in the oil and gas subsector. The two entities conduct investigations involving potential adversaries with them. PURA has power under section 49 (3) to conduct investigations relating to grant, disposal and applications for licenses whereas EWURA has the same power under section 30 (2) (c) and (o) of the Act. Further section 12 (1) and (2) of the Act gives power to PURA to engage in the bidding process, grant, suspend and review exploration and development licenses and make rules and guidelines relating to the sub-sector. Non-compliance with directives of PURA amounts to an offence under section 12 (3) of the Act.

It should also be noted that under section 111 (3), where the amount of compensation to be paid is in dispute, the matter shall be resolved by PURA, in accordance with the dispute settlement provisions contained in Part XI of the Act. This provision attempts to oust the jurisdiction of courts and in therefore is gauged in a manner that seeks to deny access to courts by litigants in the oil and gas subsector.

52 See section 186 (4) of the Petroleum Act.

53 See section 247 (3) of the Act. 


\section{Ancillary Legislation}

Some provisions in the body of laws that may seem to have no bearing on the oil and gas sectors are relevant and must be addressed in a holistic approach in the management of the oil and gas sector as they also have implications to access and management of the oil and gas resources. A review of some of these ancillary laws is relevant:

\section{a) Local Government (District) Authorities Act, 1982}

The general functions of local government authorities established under the Local Government (District) $\mathrm{Act}^{54}$ (the Act), comprising of District Councils, Township Authorities and Village Councils also have a bearing on the oil and gas sub-sector. Section 114 of the Act gives powers to local governments to access land by way of acquisition of land or access any land within or outside its areas of jurisdiction or request the President to acquire such land. Compensation for land acquired under this section is to be paid by the President as provided for under the Land Acquisition Act, 1967. The Act does not provide exceptions to the kind or types of land which may be acquired and this respect, land upon which oil and gas operations and developments could fall into this category, potentially pitting local government at logger heads with Institutions under the Petroleum Act. Of course, local governments are required to consult the Minister, but there are incidences where despite such provisions, conflicting institutional mandates are on record.

Other activities in which local government authorities under the Act could have an impact on the oil and gas sub-sector are those found in their power relating to use of land. Under section 114 (2) local governments can request the President to revoke a land of occupancy. Such revocation may include land where operations relating to the oil sub-sector are undertaken. Also, section 118 (1) (e) gives District Councils power to regulate and coordinate development plans where similar activities could be affected. Similarly, section 118 (2) (h) empowers the Councils to prepare planning schemes relating to inter alia, the development of areas in their jurisdictions. Section 142 (2) (a) is more direct. It gives powers to Village Councils to plan and coordinate activities related to any industry, including the oil and gas sub-sector.

If not properly regulating and coordinated, the exercise of through the by-law making power vested in local government authorities is yet another area where conflicts over access to areas where oil and gas operations or developments may arise. The Local Government (District) Authorities Act, empower local governments to make by-laws with a wide scope, covering potential areas where oil and gas operations and developments could be affected. ${ }^{55}$

In order to ensure efficiency in the performance of their roles as guardians of the environment in their localities, the $1^{\text {st }}$ Schedule to the Act gives power to District Councils to

54 Cap. 287 [R.E. 2002].

55 See sections 148, 115 and 163 of the Act which vest by-law making power to District Councils, Township Authorities and Village Councils, respectively. 
declare any area of land to be reserved land for purposes of reconditioning. This power does not exempt the Councils from reserving land that is used or intended for use for oil and gas related activities or operations. Similarly, item 91 of the Schedule empower the Councils to prevent pollution while item 98, which has a direct bearing to oil and gas, gives the Councils to regulate use of, inter alia, waste relating to water, oil and gas.

\section{b) Local Government (Urban) Authorities Act, 1982}

The Local Government (Urban) Authorities Act provides for the establishment of urban based local government authorities (Urban Councils) under the jurisdiction of the Minister responsible for local government affairs. The Urban Councils are made of governing organs in charge of Townships, Municipalities and City Councils.

Sections 60 of this Act provides for powers of urban authorities to acquire land and 80 provides for their power to make by-laws. These provisions have a bearing on the oil and gas sub-sector where operations can be affected by the exercise of the powers. The overall functions of urban authorities stipulated in the Schedule to the Act are in all aspects relevant to developers engaged in oil and gas operations. Item 5 which give power to urban authorities to declare reserved lands, in lands under their jurisdictions is directly relevant in this regard. These provisions, like similar powers relating to accessing and acquisition of land under the Local Government (District) Authorities Act discussed above are relevant and may have implications for in the oil and gas subsector.

\section{c) Environmental Management Act, 2004}

The Environmental Management Act, $2004^{56}$ (EMA) is the overall framework environmental law and it overrides any other natural resources section sector legislation in relation to the management and protection of the environment. EMA is a very important piece of law in regulating the oil and gas industries whose activities have a significant bearing on the environment. In this regard, the provisions of EMA that address issues of waste management, environmental quality standards, environmental restoration and Environmental Impact Assessment (EIA), among other matters are relevant.

EMA also requires authorities charged with the management of the environment to ensure that activities, including oil and gas exploration, take into account Multilateral Environmental Agreements (MEAs) that have a bearing on the oil and gas industry international legal instruments. The authorities are also required to ensure compliance with principles of environmental management outlined in EMA, such as the polluter pays, precautionary, inter and intra generational and sustainable development principles, in the enforcing the Act. These principles have a direct bearing on the oil and gas industry. 
The Act vests the management of environmental issues in the Minister of Environment and vests in him the power to determine the issuance of licenses and approve EIAs relating to the oil and gas sector. The Act establishes the National Environmental Management Council (NEMC) as an advisory body to the Minister. NEMC is also vested with the power to oversee Environmental Impact Assessment and related assessments under the Act. The importance of EIA in oil and gas activities cannot be overemphasized. In this regard, the government has put in place detailed EIA Regulations which address oil and gas exploration. ${ }^{57}$ EMA makes it mandatory for certain developments, including oil and gas, to be preceded by an Environmental Impact Assessment. ${ }^{58}$

The Act clearly provides that in the event of a conflict on the procedure of conducting EIA, in the course of undertaking oil and gas activities, whether in principal or subsidiary legislation, the provisions of the EMA would prevail to the extent of the inconsistency.

\section{Environmental Impact Assessment (EIA)}

Although other natural resources sector legislation and ancillary laws which have a bearing on the activities related to the oil and gas industry also provide for the need to carry out EIA, among other things, in certain developments, detailed regulations of how the EIA procedure relating to the activities/developments, including oil and gas, are provided for in this Act.

Section 81 (1) of EMA is clear on this where it provides:

"Any person, being a proponent or a developer of a project or undertaking of a type specified in the Third Schedule to this Act, to which Environmental Impact Assessment is required to be made by the law governing such project or undertaking or in the absence of such law, by regulations made by the Minister."

An important requirement of the EIA process is that the developer or one undertaking oil and gas explorations must consult, among other stakeholders, the local community where such development is to be undertaken. The EIA Regulations also seek to ensure that local community members in areas affected by oil and gas activities have access to information. ${ }^{59}$

\section{Model PSA}

Operations in the oil and gas industry entail activities that if not adequately regulated, would have adverse effects on the environment. The Model PSA put in place by the government through TPDC in 2013 seeks to address environmental harms likely to be caused

57 See the Environmental Impact Assessment and Audit Regulations, 2005 (G.N. No. 349 of 2005).

58 See the First Schedule of the EIA Regulations, Item A-8(i) - (vi).

59 See Regulations 17, 26, 27, 28 (3) and 29. 
by upstream activities. Articles 22 and 25 of the 2013 Model PSA are relevant in this regard.

The Model PSA requires operators to ensure they comply with health safety and environmental laws and makes cross reference to some of the relevant and applicable legislation. Most notable legislative enactments referred to in this regard are the Occupational Health and Safety Act 2003, the Atomic Energy Act 2003 and the Pharmaceuticals and Poisons Act 1978 (Cap. 219) set out in Article 25. This Article also requires operators to comply with international legal instruments relating to health safety and environment. It specifically calls upon contractors to ensure they achieve international standards set out in, among other international legal bodies, the International Organisation for Standardizations (ISO), the International Maritime Organization (IMO), the International Electro-technical Commission (IEC) and the International Petroleum Industry Environmental Conservation Association (IPIECA).

\section{F. Conclusions and Recommendations}

The review above has shown that the legislative regime governing the oil and gas industry in Tanzania must be viewed from the historical context of the Union between Tanganyika and Zanzibar to form the United Republic of Tanzania. Issues of oil and gas remain controversial with regard to the Constitutional context, at least at the time of writing. The review has focused of the legislative regime pertaining on Tanzania Mainland.

It has been noted that the body of laws for the management of oil and gas in Tanzania is found in a number of segmented sector laws governing natural resources generally and a number of ancillary laws. Despite the numerous laws, the main legislative framework governing the oil and gas industry is the Petroleum Act. It has been noted that in order to fully understand the legal regime governing the oil and gas sector, it is necessary to have a thorough understanding of the provisions of the ancillary laws, especially those relating to local government authorities, land and environment. The international legal instruments relating to oil and gas explorations must also be taken into account in analysing the legal framework of oil and gas in Tanzania. The Model PSA is also an important document that provides for the legal obligations between the government and investors in the oil and gas sector.

The legislative regime for oil and gas in Tanzania places the management of the resources in the government. The laws establish authorities and empower them to regulate exploration and related activities by way of licenses, which are transferable and can be revoked by following the laid down procedure. Access rights to land in areas where oil and gas operations are conducted place local communities in a rather unfortunate state. They are not guaranteed fair and adequate compensation as the provisions of the law give the authorities discretion on determining such compensation. The provisions of the Petroleum Act provide for little room for appeal and its provisions relating to compensation are contrary to the 
principles of natural justice as the decision of the authorities are not appealable to courts of law.

In terms of environmental health and safety, the regulatory regime is relatively fair in terms of access to information by local communities likely to be affected. However, NEMC is limited as it does not have branches in the whole country due to, inter alia, financial constraints. It, therefore, cannot effectively monitor environmental compliance by the operators in the oil and gas industry.

The Petroleum Act, being the framework legislation governing the oil and gas subsector in Tanzania is still at the very embryonic stage. In order to become fully operational, Regulations contemplated in it must be promulgated. The process of having these in place will certainly take time but need to be detailed enough to address the details required in such a sector. The implementation of the Act should be gradual and should also leave room for amendment to ensure that other ancillary laws do not conflict. The process of amending the law should also take into account the limitations of access and management rights that have been brought to the fore in this analysis. 